EXTENDED REPORT

\title{
A randomised placebo controlled 12 week trial of budesonide and prednisolone in rheumatoid arthritis
}

\author{
J R Kirwan, R Hällgren, H Mielants, F Wollheim, E Bjorck, T Persson, C Book, S Bowman, M Byron, \\ N Cox, M Field, L Kanerud, M Leirisalo-Repo, M Malaise, A Mohammad, R Palmer, I F Petersson, \\ B Ringertz, P Sheldon, M Simonsson, N Snowden, F Van den Bosch
}

Ann Rheum Dis 2004;63:688-695. doi: 10.1136/ard.2003.008573

See end of article for authors' affiliations

Correspondence to: Dr John R Kirwan, Academic Rheumatology Unit, University Division of Medicine, Bristol Royal Infirmary, Bristol BS2 8HW, UK; john.kirwan@ bristol.ac.uk

Accepted 29 June 2003
Objectives: To compare budesonide, a locally acting glucocorticoid with minimal systemic exposure, with conventional glucocorticoid treatment and placebo in rheumatoid arthritis.

Methods: A double blind, randomised, controlled trial over 12 weeks in 143 patients with active rheumatoid arthritis, comparing budesonide $3 \mathrm{mg}$ daily, budesonide $9 \mathrm{mg}$ daily, prednisolone $7.5 \mathrm{mg}$ daily, and placebo. Particular attention was paid to the pattern of clinical response and to changes in the four week period following discontinuation of treatment.

Results: There were improvements in tender joint count and swollen joint count on budesonide $9 \mathrm{mg}$ compared with placebo (28\% for tender and $34 \%$ for swollen joint counts, $\mathrm{p}<0.05)$. Prednisolone $7.5 \mathrm{mg}$ gave similar results, while budesonide $3 \mathrm{mg}$ was less effective. ACR20 response criteria were met by $25 \%$ of patients on placebo, $22 \%$ on budesonide $3 \mathrm{mg}, 42 \%$ on budesonide $9 \mathrm{mg}$, and $56 \%$ on prednisolone $7.5 \mathrm{mg}$. A rapid and significant reduction in symptoms and signs in response to budesonide $9 \mathrm{mg}$ and prednisolone $7.5 \mathrm{mg}$ was evident by two weeks and maximal at eight weeks. There was no evidence that budesonide provided a different pattern of symptom control from prednisolone, or that symptoms became worse than placebo treatment levels after discontinuation of glucocorticoid treatment. Adverse effects attributable to glucocorticoids were equally common in all groups.

Conclusions: The symptomatic benefits of budesonide $9 \mathrm{mg}$ and prednisolone $7.5 \mathrm{mg}$ are achieved within a short time of initiating treatment, are maintained for three months, and are not associated with any rebound in symptoms after stopping treatment.
$\mathrm{R}$ heumatoid arthritis is a disease of synovial inflammation in which the gut may have a pathophysiological role. $^{1-3}$ Attempts to influence joint inflammation by altering the antigen load to the gut have used antibiotics, diet, and fasting. ${ }^{4-6}$ Gut infection or inflammation is associated with arthritis in Whipple's disease and the spondylarthropathies (ankylosing spondylitis, reactive arthritis, and arthritis of inflammatory bowel disease). ${ }^{78}$ The ileocaecal region is an area of particular interest in the search for a pathophysiological link between the gut mucosal immune system and joint inflammation.

Glucocorticoids are effective in suppressing the symptoms of inflammation in rheumatoid arthritis in the short ${ }^{9}$ and medium term, ${ }^{10}{ }^{11}$ but long term continuing benefit has been questioned. ${ }^{12}$

Budesonide (Entocort ${ }^{\circledR}$ ) is a glucocorticoid that is formulated in controlled ileal release (CIR) capsules, which are designed to release budesonide mainly in the ileocaecal region. Budesonide is a potent non-halogenated synthetic glucocorticosteroid which undergoes an extensive degree of biotransformation (approximately $90 \%$ ) in the liver to metabolites with low glucocorticosteroid activity. The glucocorticosteroid activity of the major metabolites $6 \beta$-hydroxybudesonide and $16 \alpha$-hydroxyprednisolone is less than $1 \%$ of that of budesonide. Thus budesonide has rapid and extensive first pass metabolism in the liver. As a result it has proved an effective method of delivering high activity of glucocorticoid to the gut with relatively low plasma concentrations, ${ }^{13}{ }^{14}$ thus offering a reduced risk of systemic side effects and enhanced tolerability compared with conventional glucocorticoid treatment. The efficacy of budesonide in the treatment of ulcerative colitis and Crohn's disease has been demonstrated in clinical studies using enema and CIR capsules, respectively. ${ }^{15-18}$

This study is based on the hypothesis that budesonide CIR might normalise and modify the intestinal immune response and thereby indirectly induce and maintain control of the joint inflammation over and above the effect of glucocorticoid systemically available. If so, the response to budesonide might differ from the response to other oral glucocorticoids such as prednisolone given in a dose that produces equivalent systemic glucocorticoid concentrations. We therefore undertook a randomised, double blind, placebo controlled trial of the symptom relieving efficacy over 12 weeks of budesonide CIR 9 mg daily in active rheumatoid arthritis compared with placebo. Additional treatment arms included budesonide CIR $3 \mathrm{mg}$ daily and prednisolone $7.5 \mathrm{mg}$ daily, as the clinical response to prednisolone is not well characterised over this time period. In addition to overall efficacy at 12 weeks, particular attention was paid to the shape of the symptom response curves to assess any difference in pattern between budesonide and prednisolone. The study subjects were followed in double blind fashion for four weeks after discontinuation of trial medication to monitor the pattern of symptom return following each treatment arm.

\section{METHODS \\ Objectives}

The primary objective was to compare the symptom relieving capacity of budesonide CIR $9 \mathrm{mg}$ against placebo after 12 weeks treatment in patients with rheumatoid arthritis. The primary outcome variables were tender joint count and swollen joint count. The secondary objectives were to compare the symptom relieving efficacy of budesonide CIR 
$9 \mathrm{mg}$, budesonide CIR $3 \mathrm{mg}$, prednisolone $7.5 \mathrm{mg}$, and placebo after 12 weeks of treatment; to investigate whether there is any indication of a difference in symptom relief between the study treatments at the beginning of the treatment period and after the study treatment was withdrawn; to assess quality of life during the study; and to assess safety of the treatments during the study, concentrating particularly on potential systemic side effects of glucocorticoids.

The study was approved by the local research ethics review body at each participating institution.

\section{Design}

The study was a randomised, double blind, double dummy, placebo controlled, multicentre study with four parallel treatment groups: budesonide CIR $9 \mathrm{mg}$; budesonide CIR 3 $\mathrm{mg}$; prednisolone $7.5 \mathrm{mg}$; or placebo once daily. Treatment was for 12 weeks, with a further four weeks of follow up. The double blind nature of the study was maintained until after all patients had completed the follow up period. There were 16 recruitment centres in all, in Belgium, Sweden, and the United Kingdom.

\section{Patients}

Outpatients with rheumatoid arthritis according to the criteria of the American College of Rheumatology (ACR), ${ }^{19}$ with onset of the disease over the age of 16 years and who met the inclusion criteria, were invited to take part in the study. They were men or women aged between 18 and 80 years with active disease as shown by the presence of early morning stiffness of at least 45 minutes and six or more tender joints, of which at least three had soft tissue swelling and tenderness. Patients were of functional capacity class IIII according to Steinbrocker ${ }^{20}$ and had either no treatment with or a stable dose of non-steroidal anti-inflammatory drugs (NSAIDs) or analgesics for at least 30 days, no treatment with or a stable dose of disease modifying antirheumatic drugs (DMARDs) for at least 90 days, and no glucocorticoids by any route for at least 30 days.

Patients were excluded from the study if they were pregnant, planned pregnancy, or were breast feeding; if they had systemic lupus erythematosus, polymyalgia rheumatica, psoriatic arthropathy, spondyloarthropathy (ankylosing spondylitis, reactive arthritis, undifferentiated spondyloarthropathy, and inflammatory bowel disease), amyloidosis, active peptic ulcer disease, uncontrolled diabetes mellitus or other significant disease as judged by the investigator; if there was local or systemic infection that might contraindicate glucocorticoid use; if they had allergy to budesonide or other glucocorticoids; if there was immunisation with live viruses (for example, polio) or live bacteria (for example, tubercle bacilli) during the previous 90 days; or if they had undergone resection of the stomach or more than $100 \mathrm{~cm}$ of the small bowel. Rheumatoid factor status and the presence of radiographic erosions in the hands and feet were determined at entry.

\section{Outcome variables}

Outcome variables were those recommended by OMERACT (Outcome Measures in Rheumatology Clinical Trials). ${ }^{21}$ Primary outcomes were the number of tender joints and the number of swollen joints (28 joint count). ${ }^{22}$ Secondary outcomes were the patient's assessment of pain $(100 \mathrm{~mm}$ visual analogue scale), the patient's global assessment of disease activity (100 $\mathrm{mm}$ visual analogue scale), the clinician's global assessment of disease activity (asymptomatic, mild, moderate, severe, very severe), self report of physical function (the health assessment questionnaire $\left(\mathrm{HAQ}^{23}\right)$ as adapted in the participating countries ${ }^{24}{ }^{25}$ ), the 36 item short form health survey $\left(\mathrm{SF}-36^{26}\right)$, and the acute phase reactants C-reactive protein (CRP) and erythrocyte sedimentation rate (ESR). Patient's report of morning stiffness (minutes) was also recorded. The ACR20 response criteria $^{27}$ were also applied ( $20 \%$ improvement in tender joint count, $20 \%$ improvement in swollen joint count, and $20 \%$ improvement in any three of pain, patient's global assessment, physician's global assessment, disability, and the acute phase response).

\section{Safety variables}

Safety variables included a specific inquiry for adverse events and a checklist of potential glucocorticoid adverse effects (moon face; buffalo hump; acne; hirsutism; purple skin striae; bruising easily; hair loss; swelling of ankles; mood swings; depression; insomnia), blood pressure, body weight, and laboratory assessments including biochemistry, liver enzymes, inflammatory markers, and blood glucose. Measurement of adrenal function was undertaken the day after discontinuation of treatment and will be reported elsewhere.

\section{Treatment}

Following informed consent, patients were assessed over a run-in period of up to two weeks to ensure they were eligible for the study. Outcome and safety variables were measured, and patients allocated to the next available study number. Drugs were dispensed by the hospital pharmacy in relation to the study number and in accordance with a predefined sequence of randomly generated allocations kept in sealed envelopes. Each patient was equally likely to be allocated to any of the four treatment arms. In addition to their existing drug treatment each patient took three study preparations each day. One preparation was either budesonide $9 \mathrm{mg}$, budesonide $3 \mathrm{mg}$, or budesonide placebo, all of which were

\begin{tabular}{|c|c|c|c|c|c|}
\hline & $\begin{array}{l}\text { Budesonide } \\
3 \mathrm{mg}\end{array}$ & $\begin{array}{l}\text { Budesonide } \\
9 \mathrm{mg}\end{array}$ & $\begin{array}{l}\text { Prednisolone } \\
7.5 \mathrm{mg}\end{array}$ & Placebo & Total \\
\hline Randomised & 37 & 36 & 39 & 31 & 143 \\
\hline Lost to follow up & 0 & 1 & 0 & 0 & 1 \\
\hline $\begin{array}{l}\text { treat analysis } \\
\text { Discontinued study }\end{array}$ & 37 & 35 & 39 & 31 & 142 \\
\hline medication & 7 & 6 & 3 & 7 & 23 \\
\hline Symptom deterioration* & 5 & 3 & 1 & 3 & 12 \\
\hline Adverse event* ${ }^{*}$ & 1 & 2 & 1 & 2 & 6 \\
\hline $\begin{array}{l}\text { Other reasons* } \\
\text { Completed study }\end{array}$ & 3 & 0 & 1 & 2 & 6 \\
\hline medication & 30 & 30 & 36 & 24 & 120 \\
\hline
\end{tabular}


prepared as identical capsules. The other two preparations were either prednisolone $5 \mathrm{mg}$ plus prednisolone $2.5 \mathrm{mg}$, or identical prednisolone $5 \mathrm{mg}$ placebo and $2.5 \mathrm{mg}$ placebo tablets. Treatment was continued for 12 weeks. The study drug treatment was then discontinued. Rescue treatment (paracetamol $1 \mathrm{~g}$ up to four times daily) was available at the patient's discretion. The use of rescue treatment during the previous weeks was recorded at each study visit. All nonstudy drugs were continued unchanged throughout the study period of 16 weeks. Adherence to the dosing instructions was checked at two, four, eight, and 12 weeks by asking patients if they had omitted any study medication and counting returned unopened treatment packs. Patients who took less than $80 \%$ of treatment, or who interrupted study treatment for more than three consecutive days, were considered to be non-adherent. Any drugs required for other conditions were continued.

Doses of budesonide and prednisolone were chosen to provide approximately equal systemic glucocorticoid effects for the prednisolone treatment and for the higher dose of budesonide. In a cortisol suppression dose-response study, ${ }^{28}$ $29 \mathrm{mg}$ budesonide produced similar responses to $20 \mathrm{mg}$ prednisolone.

\section{Assessments}

Following allocation to a study number at baseline, patients were assessed and at weeks $0,2,4,8,12$, and 16. Patient discontinuing the study were, if possible, assessed at the time of or soon after discontinuation. Unused study drugs and rescue drugs were returned. The patient was assessed at 12 weeks after start of study treatment. Between weeks 13 and 16, patients completed weekly assessment cards including records of pain, global assessment, and morning stiffness, and recorded their drug intake in a notebook. This allowed an evaluation of the rapidity of change in symptoms following discontinuation of study treatment.

\section{Study size}

The study was powered to detect a difference in effect size for swollen or tender joint counts between any two groups of 0.7 (equivalent to an absolute difference in change in joint count of about 1). Based on published standard deviations, $\alpha=0.05$ and $\beta=0.80$, a sample size of 35 patients per treatment group was calculated, and the recruitment target set at 140 patients.

\section{Statistical analysis}

To compare the pattern of response for each variable by visual inspection, means and 95\% confidence intervals (CI) were calculated for each time point for each treatment group, expressed as a percentage of the combined baseline value for that variable with all patients taken together, and used to plot the figures. Absolute differences in mean values between groups and their statistical significance were calculated from analysis of variance, and are expressed in the tables after adjustment for baseline differences. For patients who missed one assessment the value of the previous assessment was carried forward to that assessment (last value extended principle). Early morning stiffness was not normally distributed and geometric means were used for statistical calculations.

\section{RESULTS}

Of the 143 patients who were randomised into the study, one patient did not receive any study preparations and is thus not included in the analysis. The flow of patients through the study is illustrated in table 1. Table 2 shows the

Table 2 Patient characteristics (mean values or proportions)

\begin{tabular}{|c|c|c|c|c|c|c|}
\hline & & \multicolumn{5}{|c|}{ Treatment groups } \\
\hline & & $\begin{array}{l}\text { Budesonide } \\
3 \mathrm{mg}\end{array}$ & $\begin{array}{l}\text { Budesonide } \\
9 \mathrm{mg}\end{array}$ & $\begin{array}{l}\text { Prednisolone } \\
7.5 \mathrm{mg}\end{array}$ & Placebo & Combined \\
\hline $\begin{array}{l}\mathrm{N} \\
\text { Age (years) } \\
\text { Proportion female (\%) } \\
\text { Weight (kg) } \\
\text { Height (cm) } \\
\text { Disease duration (years) } \\
\text { Proportion with erosions (\%) } \\
\text { Number taking NSAIDs } \\
\text { Number taking DMARDs }\end{array}$ & & $\begin{array}{l}37 \\
54.2 \\
70 \\
73.5 \\
166 \\
13.1 \\
84 \\
30 \\
28\end{array}$ & $\begin{array}{l}35 \\
57.8 \\
77 \\
74.6 \\
165 \\
8.5 \\
66 \\
27 \\
25\end{array}$ & $\begin{array}{l}39 \\
53.4 \\
62 \\
73.9 \\
168 \\
7.0 \\
54 \\
30 \\
26\end{array}$ & $\begin{array}{l}31 \\
54.7 \\
77 \\
71.4 \\
166 \\
7.2 \\
87 \\
26 \\
20\end{array}$ & $\begin{array}{l}142 \\
55.0 \\
71 \\
73.4 \\
166 \\
9.0 \\
72 \\
113 \\
99\end{array}$ \\
\hline Disability (HAQ) score & $\begin{array}{l}\text { Baseline } \\
12 \text { weeks }\end{array}$ & $\begin{array}{l}1.61 \\
1.57\end{array}$ & $\begin{array}{l}1.57 \\
1.41\end{array}$ & $\begin{array}{l}1.51 \\
1.11\end{array}$ & $\begin{array}{l}1.52 \\
1.48\end{array}$ & 1.55 \\
\hline Tender joint count & $\begin{array}{l}\text { Baseline } \\
12 \text { weeks }\end{array}$ & $\begin{array}{l}14.2 \\
11.0\end{array}$ & $\begin{array}{l}11.8 \\
7.7\end{array}$ & $\begin{array}{l}12.3 \\
6.6\end{array}$ & $\begin{array}{l}12.6 \\
11.7\end{array}$ & 12.7 \\
\hline Swollen joint count & $\begin{array}{l}\text { Baseline } \\
12 \text { weeks }\end{array}$ & $\begin{array}{l}12.9 \\
10.2\end{array}$ & $\begin{array}{l}9.8 \\
6.2\end{array}$ & $\begin{array}{l}11.6 \\
7.2\end{array}$ & $\begin{array}{l}11.8 \\
11.5\end{array}$ & 11.5 \\
\hline Patient's assessment of pain $(\mathrm{mm})$ & $\begin{array}{l}\text { Baseline } \\
12 \text { weeks }\end{array}$ & $\begin{array}{l}54.1 \\
47.9\end{array}$ & $\begin{array}{l}65.5 \\
47.6\end{array}$ & $\begin{array}{l}49.2 \\
28.8\end{array}$ & $\begin{array}{l}56.9 \\
54.8\end{array}$ & 56.2 \\
\hline Patient's global assessment of disease activity & $\begin{array}{l}\text { Baseline } \\
12 \text { weeks }\end{array}$ & $\begin{array}{l}50.6 \\
48.1\end{array}$ & $\begin{array}{l}59.0 \\
42.4\end{array}$ & $\begin{array}{l}54.4 \\
31.8\end{array}$ & $\begin{array}{l}54.4 \\
55.8\end{array}$ & 54.5 \\
\hline Clinician's global assessment of disease activity & $\begin{array}{l}\text { Baseline } \\
12 \text { weeks }\end{array}$ & $\begin{array}{l}3.1 \\
2.8\end{array}$ & $\begin{array}{l}3.2 \\
2.7\end{array}$ & $\begin{array}{l}3.0 \\
2.3\end{array}$ & $\begin{array}{l}3.1 \\
3.0\end{array}$ & 3.1 \\
\hline Early morning stiffness (minutes) & $\begin{array}{l}\text { Baseline } \\
12 \text { weeks }\end{array}$ & $\begin{array}{l}111 \\
54\end{array}$ & $\begin{array}{l}98 \\
73\end{array}$ & $\begin{array}{l}93 \\
73\end{array}$ & $\begin{array}{l}105 \\
94\end{array}$ & 102 \\
\hline $\mathrm{C}$ reactive protein $(\mathrm{mg} / \mathrm{l})$ & $\begin{array}{l}\text { Baseline } \\
12 \text { weeks }\end{array}$ & $\begin{array}{l}22.5 \\
21.0\end{array}$ & $\begin{array}{l}32.9 \\
33.3\end{array}$ & $\begin{array}{l}30.2 \\
10.8\end{array}$ & $\begin{array}{l}39.9 \\
34.2\end{array}$ & 28.8 \\
\hline
\end{tabular}



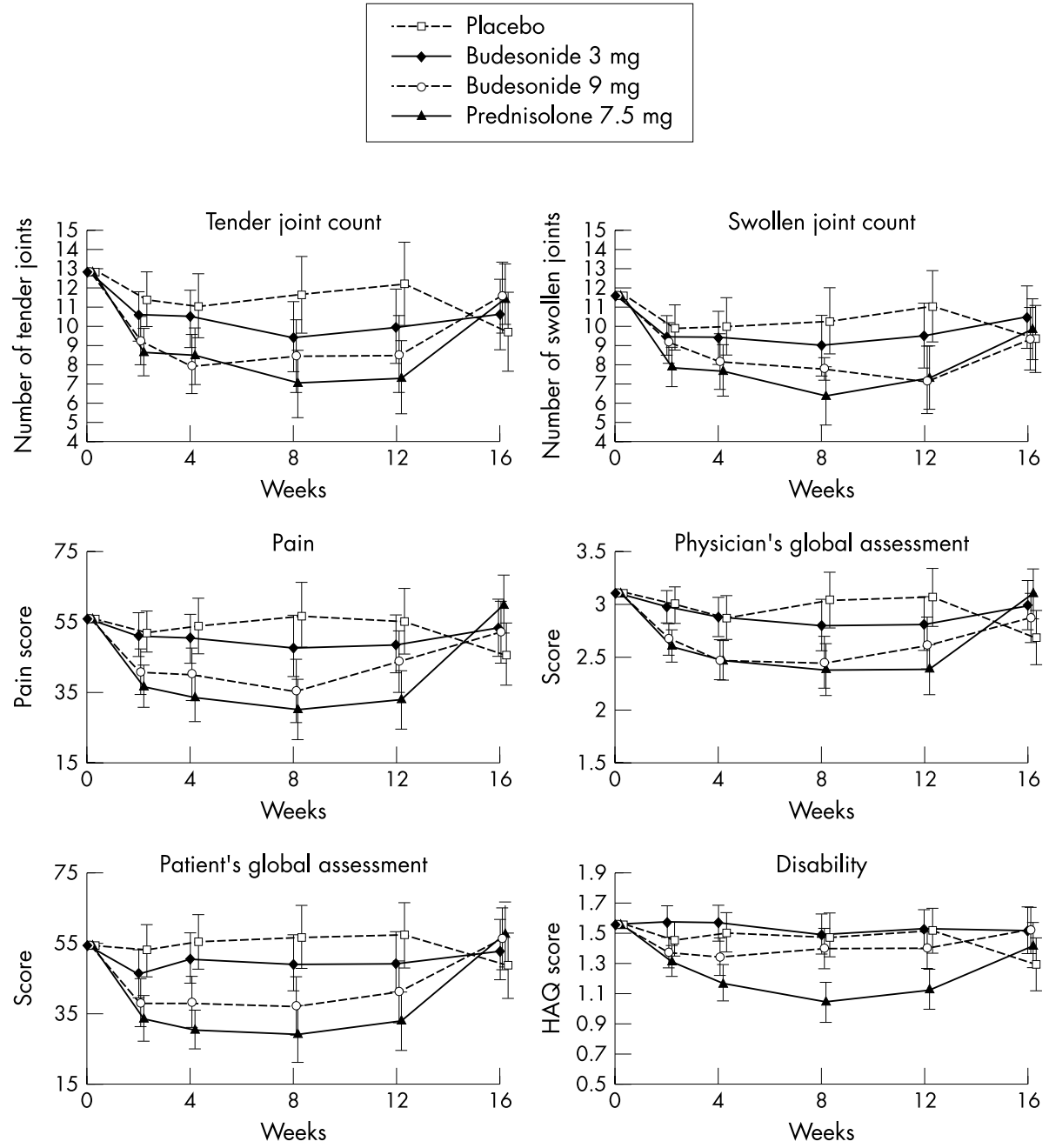

Figure 1 Changes in clinical symptoms during the study (means and 95\% confidence intervals). Study treatment was for 12 weeks.

characteristics of the patients included in the intention to treat analysis. The specific antirheumatoid drugs taken by the patients were methotrexate $(47 \%)$, sulphasalazine $(31 \%)$, hydroxychloroquine $(6 \%)$, and others $(16 \%)$ (minocycline, gold, penicillamine). There were no significant differences between groups for the baseline variables. The standard deviations for the primary outcome variables for all groups taken together were: tender joint count 5.72; swollen joint count 5.06.

The mean and 95\% confidence intervals (CI) for the primary outcome measures (tender joint count and swollen joint count) for each treatment group at each time point are shown in fig 1 together with charts for pain, patient's global assessment, clinician's global assessment, and disability (HAQ). Differences in outcomes between treatment groups at 12 weeks, adjusted for baseline differences, are shown in table 3.

After adjustment for baseline differences, there were significant improvements at 12 weeks in the budesonide 9 $\mathrm{mg}$ group, over and above the placebo response, in tender joint count $(3.65,28.6 \%, \mathrm{p}=0.014)$ and swollen joint count $(3.81,32.9 \%, p=0.003)$. Of the secondary outcome variables, there were improvements in patient's assessment of disease activity $(15.9,29.2 \%, p=0.012)$, physician's assessment of disease activity $(0.45,14.5 \%, \mathrm{p}=0.019)$, and early morning stiffness (geometric mean 0.37, 24.9\%, p =0.016), and there was a trend for pain improvement $(21.7 \%, p=0.078)$.
Similar or slightly larger benefits over placebo were evident for prednisolone $7.5 \mathrm{mg}$ : tender joint count 4.83, 37.9\%, $\mathrm{p}=0.001$; swollen joint count 3.67, 31.7\%, $\mathrm{p}=0.003$; patient's assessment 24.6, 45.1\%, p=0.0002; physician's assessment $0.67,21.5 \%, \mathrm{p}=0.0004$; early morning stiffness $0.473,31.6 \%, p=0.002$; and pain $22.3,39.8 \%, p=0.001$. In addition, there was a clear improvement in functional capacity in the prednisolone $7.5 \mathrm{mg}$ group compared to both placebo $(0.38,24.6 \%, \mathrm{p}=0.0002)$ and budesonide $9 \mathrm{mg}$ (difference $0.27,17.6 \%, \mathrm{p}=0.004$ ). The results for the budesonide $3 \mathrm{mg}$ generally fell between the placebo and budesonide $9 \mathrm{mg}$ groups, and were not significantly different from either. The acute phase response, measured by $\mathrm{C}$ reactive protein, showed a significant reduction greater than that for placebo for budesonide $3 \mathrm{mg}$ (geometric mean difference $0.23, \mathrm{p}=0.01 \mathrm{l}$ ) and prednisolone $7.5 \mathrm{mg}$ (geometric mean difference $0.48, \mathrm{p}<0.00001$ ), but not for budesonide $9 \mathrm{mg}$. However, the budesonide $9 \mathrm{mg}$ group had similar significant reductions as the budesonide $3 \mathrm{mg}$ group at all other treatment time points.

At 12 weeks the proportion of patients (with 95\% CI) who met the ACR20 response criteria were: placebo, $25 \%$ (10\% to $40 \%$ ); budesonide $3 \mathrm{mg}, 22 \%$ ( $9 \%$ to $35 \%$ ); budesonide $9 \mathrm{mg}$, $42 \%$ (26\% to $58 \%$ ); and prednisolone $7.5 \mathrm{mg}, 56 \%$ (40\% to $72 \%)$. There was no significant difference between placebo and budesonide $3 \mathrm{mg}(\mathrm{p}=0.56)$, or between budesonide 9 $\mathrm{mg}$ and prednisolone $7.5 \mathrm{mg}(\mathrm{p}=0.11)$, and both the latter 
Table 3 Differences between treatment groups in the change in primary and secondary outcome measures between baseline and 12 weeks (after adjustment for baseline values)

\begin{tabular}{|c|c|c|c|c|c|c|}
\hline \multirow[b]{3}{*}{ Outcome } & \multicolumn{6}{|c|}{ Difference from placebo } \\
\hline & \multicolumn{2}{|c|}{ Budesonide $3 \mathrm{mg}$} & \multicolumn{2}{|c|}{ Budesonide $9 \mathrm{mg}$} & \multicolumn{2}{|c|}{ Prednisolone $7.5 \mathrm{mg}$} \\
\hline & Mean & $(95 \% \mathrm{Cl})$ & Mean & $(95 \% \mathrm{Cl})$ & Mean & $(95 \% \mathrm{Cl})$ \\
\hline $\begin{array}{l}\text { Tender joint count } \\
\text { Swollen joint count } \\
\text { Pain } \\
\text { Disease activity (patient) } \\
\text { Disease activity (physician) } \\
\text { EMS } \\
\text { Geometric EMS }\left(\log ^{10}\right) \\
\text { HAQ } \\
\text { CRP (mg/dl) } \\
\text { Geometric CRP }\left(\log ^{10}\right) \\
\text { PCS of SF-36 } \\
\text { MCS of SF-36 } \\
\text { ESR (mm/h) } \\
\text { ACR20 response (\%) }\end{array}$ & $\begin{array}{l}2.23 \\
1.53 \\
6.6 \\
7.9 \\
0.25 \\
35 \\
0.21 \\
0.009 \\
6.6 \\
0.23^{*} \\
2 \\
4.8 \\
3 \\
-3\end{array}$ & $\begin{array}{l}(-0.63 \text { to } 5.1) \\
(0.92 \text { to } 3.98) \\
(-5.8 \text { to } 18.9) \\
(-4.7 \text { to } 20.5) \\
(-0.12 \text { to } 0.62) \\
(-9 \text { to } 80) \\
(-0.08 \text { to } 0.5) \\
(-0.19 \text { to } 0.21) \\
(-4.8 \text { to } 18.1) \\
(0.05 \text { to } 0.41) \\
(-2 \text { to } 6) \\
(-0.8 \text { to } 10.4) \\
(-4 \text { to } 10) \\
(-17 \text { to } 23)\end{array}$ & $\begin{array}{l}3.65^{*} \\
3.81^{* *} \\
11.4 \\
16.4^{*} \\
0.45^{*} \\
17 \\
0.37^{*} \\
0.107 \\
1.9 \\
0.14 \\
3.7 \\
6.0^{*} \\
4 \\
17^{*}\end{array}$ & $\begin{array}{l}(0.75 \text { to } 6.54) \\
(1.3 \text { to } 6.52) \\
(-1.3 \text { to } 24) \\
(3.6 \text { to } 29.3) \\
(0.07 \text { to } 0.82) \\
(-28 \text { to } 62) \\
(0.07 \text { to } 0.67) \\
(-0.31 \text { to } 0.09) \\
(-9.7 \text { to } 13.4) \\
(-0.04 \text { to } 0.32) \\
(-0.4 \text { to } 7.8) \\
(0.4 \text { to } 11.7) \\
(-3 \text { to } 11) \\
(5 \text { to } 29)\end{array}$ & $\begin{array}{l}4.83^{* \star *} \\
3.67^{* *} \\
22.3^{* \star *} \\
24.5^{* \star *} \\
0.66^{* \star *} \\
21 \\
0.47^{* \star} \\
0.383^{* * *} \\
21.8^{* \star *} \\
0.46^{* * *} \\
7.4^{* * *} \\
7.2^{* *} \\
16^{* * *} \\
31^{* *}\end{array}$ & $\begin{array}{l}(2.01 \text { to } 7.65) \\
(1.25 \text { to } 6.09) \\
(10 \text { to } 34.6) \\
(12.1 \text { to } 37) \\
(0.3 \text { to } 1.03) \\
(-23 \text { to } 64) \\
(0.18 \text { to } 0.77) \\
(0.188 \text { to } 0.578) \\
(10.5 \text { to } 33.1) \\
(0.3 \text { to } 0.65) \\
(3.5 \text { to } 11.4) \\
(1.7 \text { to } 12.8) \\
(9 \text { to } 23) \\
(16 \text { to } 46)\end{array}$ \\
\hline & \multicolumn{4}{|c|}{ Difference from budesonide $3 \mathrm{mg}$} & \multicolumn{2}{|c|}{ Difference from budesonide $9 \mathrm{mg}$} \\
\hline & \multicolumn{2}{|c|}{ Budesonide $9 \mathrm{mg}$} & \multicolumn{2}{|c|}{ Prednisolone $7.5 \mathrm{mg}$} & \multicolumn{2}{|c|}{ Prednisolone $7.5 \mathrm{mg}$} \\
\hline Outcome & Mean & $(95 \% \mathrm{Cl})$ & Mean & $(95 \% \mathrm{Cl})$ & Mean & $(95 \% \mathrm{Cl})$ \\
\hline $\begin{array}{l}\text { Tender joint count } \\
\text { Swollen joint count } \\
\text { Pain } \\
\text { Disease activity (patient) } \\
\text { Disease activity (physician) } \\
\text { EMS } \\
\text { Geometric EMS }\left(\log ^{10}\right) \\
\text { HAQ } \\
\text { CRP }(\mathrm{mg} / \mathrm{d}) \\
\text { Geometric CRP }\left(\log ^{10}\right) \\
\text { PCS of SF-36 } \\
\text { MCS of SF-36 } \\
\text { ESR (mm/h) } \\
\text { ACR20 response (\%) }\end{array}$ & $\begin{array}{l}1.42 \\
2.28 \\
4.8 \\
8.5 \\
0.2 \\
19 \\
0.16 \\
0.117 \\
4.8 \\
0.09 \\
1.7 \\
1.2 \\
1 \\
20^{* \star}\end{array}$ & $\begin{array}{l}(-1.35 \text { to } 4.19) \\
(-0.13 \text { to } 4.69) \\
(-7.3 \text { to } 16.9) \\
(-3.7 \text { to } 20.8) \\
(-0.15 \text { to } 0.55) \\
(-24 \text { to } 61) \\
(-0.13 \text { to } 0.45) \\
(-0.31 \text { to } 0.07) \\
(-6.3 \text { to } 15.8) \\
(-0.08 \text { to } 0.27) \\
(-2.1 \text { to } 5.5) \\
(-4.1 \text { to } 6.5) \\
(-6 \text { to } 8) \\
(6 \text { to } 34)\end{array}$ & $\begin{array}{l}2.59 \\
2.14 \\
15.7^{* *} \\
16.6^{* *} \\
0.42^{*} \\
15 \\
0.26 \\
0.393^{* * *} \\
15.2^{* *} \\
0.24^{* *} \\
5.4^{* *} \\
2.4 \\
13^{* * *} \\
28^{* *}\end{array}$ & $\begin{array}{l}(-0.86 \text { to } 5.28) \\
(-0.16 \text { to } 4.44) \\
(4.1 \text { to } 27.4) \\
(4.8 \text { to } 28.5) \\
(0.08 \text { to } 0.77) \\
(-27 \text { to } 56) \\
(-0.01 \text { to } 0.54) \\
(0.21 \text { to } 0.58) \\
(4.4 \text { to } 25.9) \\
(0.07 \text { to } 0.41) \\
(1.8 \text { to } 9.1) \\
(-7.5 \text { to } 2.6) \\
(7 \text { to } 20) \\
(12 \text { to } 44)\end{array}$ & $\begin{array}{l}1.18 \\
0.14 \\
10.9 \\
8.1 \\
0.22 \\
4 \\
0.1 \\
0.276^{* *} \\
19.9^{* * *} \\
0.33^{* * *} \\
3.7^{*} \\
1.2 \\
12^{* * *} \\
14\end{array}$ & $\begin{array}{l}(-1.52 \text { to } 3.88) \\
(-2.2 \text { to } 2.48) \\
(-1.2 \text { to } 23.1) \\
(-4 \text { to } 20.2) \\
(-0.13 \text { to } 0.57) \\
(-39 \text { to } 47) \\
(-0.18 \text { to } 0.39) \\
(0.089 \text { to } 0.464) \\
(9.1 \text { to } 30.8) \\
(0.16 \text { to } 0.5) \\
(0 \text { to } 7.5) \\
(-6.5 \text { to } 4) \\
(6 \text { to } 19) \\
(-4 \text { to } 32)\end{array}$ \\
\hline
\end{tabular}

${ }^{*} \mathrm{p}<0.05,{ }^{* *} \mathrm{p}<0.01,{ }^{* * *} \mathrm{p}<0.001$.

ACR, American College of Rheumatology; CRP, C reactive protein; EMS, early morning stiffness; ESR, erythrocyte sedimentation rate; $H A Q$, health assessment questionnaire; MCS, mental condition subscale of SF-36; PCS, physical condition subscale of SF-36; SF-36, 36 item short form health survey.

were significantly different from both the former $(\mathrm{p}<0.001$ to $\mathrm{p}=0.02$ ). These confirm the results from the individual outcome measures, and suggest that over 12 weeks budesonide $9 \mathrm{mg}$ has an effect approaching that of prednisolone 7.5 mg for clinical symptoms.

The study included the SF-36, ${ }^{26}$ a measure of quality of life, which contains mental (MCS) and physical (PCS) subscales. The response on both subscales was non-significant for budesonide $3 \mathrm{mg}$, showed a slight improvement of $10 \%$ more than placebo in the budesonide $9 \mathrm{mg}$ group $(\mathrm{p}=0.61$ and $\mathrm{p}=0.060)$, and a clear improvement in the prednisolone $7.5 \mathrm{mg}$ group (PCS 27.8\%, p $<0.0001$; MCS $16.4 \%, \mathrm{p}=0.006$ ).

After discontinuation of treatment, all groups returned towards baseline values over the following four weeks. Inspection of fig 1 does not suggest any difference in the pattern of onset or the pattern of symptom recurrence between the budesonide $9 \mathrm{mg}$ group and the prednisolone group. However, these data relate to an intention to treat analysis, and a detailed analysis of those patients who actually completed treatment to week 12 was therefore undertaken to look specifically at the response to withdrawal of treatment. There were 122 such patients (24, 30, 31, and 37 in placebo, budesonide $3 \mathrm{mg}$, budesonide $9 \mathrm{mg}$, and prednisolone $7.5 \mathrm{mg}$ groups, respectively). In all three treatment groups there were deteriorations in the tender and swollen joint counts following treatment withdrawal, which were significantly different from zero, significantly different from the placebo group (which had a non-significant improvement in both assessments), and not statistically different from each other (table 4).

Table 4 Differences between treatment groups in the change in primary outcome measures during the four weeks after discontinuation of study therapy (after adjustment for baseline values)

\begin{tabular}{|c|c|c|c|c|c|c|}
\hline & \multicolumn{3}{|c|}{ Difference from placebo } & \multicolumn{2}{|c|}{ Difference from budesonide $3 \mathrm{mg}$} & \multirow{2}{*}{$\begin{array}{l}\text { Difference from budesonide } 9 \mathrm{mg} \\
\text { Prednisolone } 7.5 \mathrm{mg}\end{array}$} \\
\hline & $\begin{array}{l}\text { Budesonide } \\
3 \mathrm{mg}\end{array}$ & $\begin{array}{l}\text { Budesonide } \\
9 \mathrm{mg}\end{array}$ & $\begin{array}{l}\text { Prednisolone } \\
7.5 \mathrm{mg}\end{array}$ & $\begin{array}{l}\text { Budesonide } \\
9 \mathrm{mg}\end{array}$ & $\begin{array}{l}\text { Prednisolone } \\
7.5 \mathrm{mg}\end{array}$ & \\
\hline Tender joint count & $3.967^{*}$ & $4.699^{*}$ & $6.423^{* *}$ & -0.732 & -2.457 & -1.725 \\
\hline Swollen joint count & $3.858^{* *}$ & $4.012^{\star *}$ & $4.679^{* *}$ & -0.154 & -0.821 & -0.667 \\
\hline
\end{tabular}




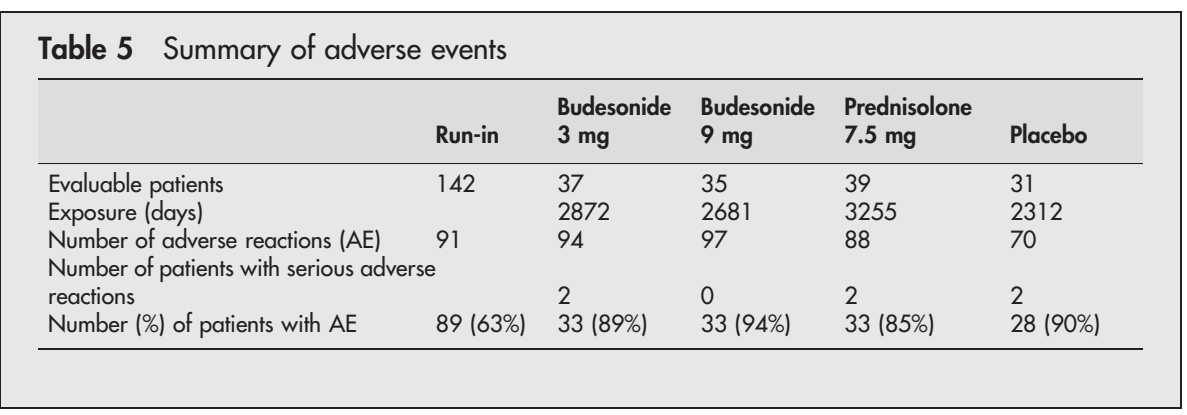

The occurrence of adverse effects is reported in tables 5 to 7. There were six serious adverse events in the study: five hospital admissions for aggravation of rheumatoid arthritis (two after completing the placebo treatment, two while taking budesonide $3 \mathrm{mg}$, one after completing budesonide 3 $\mathrm{mg}$ and one after completing prednisolone); one 56 year old woman taking budesonide $3 \mathrm{mg}$ had angina of effort (she also had aggravation of her rheumatoid arthritis); and one 58 year old man taking prednisolone with a history of ischaemic heart disease died from coronary sclerosis. Adverse events causing the patient to discontinue the study were few and included gastrointestinal symptoms, ${ }^{2}$ heart symptoms, ${ }^{3}$ and mood swings/insomnia. ${ }^{1}$ They occurred at similar rates in all patient groups. The reported occurrence of the most common adverse events (table 6) was evenly distributed in all treatment groups and in the placebo group. Potential glucocorticoid side effects (table 7), actively sought for by checklist, were reported in many patients and occurred in all patient groups, with no clinically important differences. There were no statistically significant changes in mean weight or blood pressure in any treatment group during the study.

\section{DISCUSSION}

In this study of three doses of glucocorticoid compared with placebo over 12 weeks we found a rapid and significant reduction in the symptoms and signs of rheumatoid arthritis in patients treated with budesonide $9 \mathrm{mg}$ and prednisolone $7.5 \mathrm{mg}$, and a non-significant but consistent response to budesonide $3 \mathrm{mg}$. The benefits were maximum at eight weeks but were clearly evident by two weeks of treatment. This was achieved with little in the way of additional adverse effects over and above those noted in the placebo group.

The currently available Cochrane Collaboration metaanalysis of moderate term low dose glucocorticoids for rheumatoid arthritis ${ }^{10} 29$ draws attention to the paucity of studies that directly assess the effectiveness of glucocorticoids for rheumatoid arthritis treatment, and many were of poor methodological quality. Only seven ${ }^{12}{ }^{30-35}$ of 34 studies identified met minimum criteria for inclusion in the analysis, and only four of these used a double blind design..$^{12} 313334$ These data present outcomes after periods of three months or longer. A similar review of short term glucocorticoid treatment ${ }^{9}$ concluded that there was clinical effectiveness over one week. This review also noted that the initial response (the mean difference between prednisolone and placebo was 12 on the Ritchie index, which has a maximum score of $78^{36}$ ) was much greater than the 2.4 tender joint count reduction reported over three months. ${ }^{10}$ In the present study, the reduction in tender joints was 4.83 in a scoring system with a maximum score of 28 (and 3.67 for swollen joints). This suggests that the reduction measured at one week is similar to that sustained over three months in this study. The standardised effect size in this study is 0.82 for tender joints and 0.73 for swollen joints.

Analysis of the secondary outcome variables is less clear, as the study was not powered primarily for that purpose. Nevertheless, there is good evidence that budesonide $9 \mathrm{mg}$ and prednisolone $7.5 \mathrm{mg}$ clearly reduce symptoms. In this regard, prednisolone $7.5 \mathrm{mg}$ generally produced a greater improvement. However, it should be noted that the serum levels of glucocorticoid will be higher at the time of the patient assessment in the prednisolone group, as the majority of assessments were undertaken in the morning, the treatments were taken on waking, and the absorption profile of budesonide means that peak serum levels will not be attained for several hours after ingestion. It may be that taking budesonide earlier, possibly even on going to bed, might have resulted in a greater effect.

It should also be recognised that patients in the study were receiving other antirheumatoid treatment. The benefits of budesonide $9 \mathrm{mg}$ and prednisolone $7.5 \mathrm{mg}$ in achieving an ARC20 response in about half of the patients treated were in addition to the disease control already achieved with other treatments.

\begin{tabular}{lllll} 
Table 6 & Most common spontaneously reported adverse events & \\
\hline & $\begin{array}{l}\text { Budesonide } \\
\text { 3 }\end{array}$ & $\begin{array}{l}\text { Budesonide } \\
\text { 9 } \mathbf{~ g g}\end{array}$ & $\begin{array}{l}\text { Prednisolone } \\
\mathbf{7 . 5} \mathbf{~ m g}\end{array}$ & Placebo \\
\hline Respiratory infection & 7 & 4 & 6 & 1 \\
Headache & 4 & 5 & 6 & 1 \\
Abdominal pain & 4 & 3 & 4 & 2 \\
Rheumatoid arthritis aggravated & 6 & 3 & 0 & 3 \\
Diarrhoea & 2 & 2 & 2 & 3 \\
Pain & 1 & 2 & 3 & 1 \\
Back pain & 1 & 3 & 0 & 3 \\
Haematuria & 2 & 1 & 2 & 2 \\
Infection, viral & 4 & 1 & 0 & 0 \\
Anaemia & 1 & 2 & 0 & 2 \\
Dyspepsia & 2 & 0 & 2 & 1 \\
Sweating increased & 1 & 2 & 1 & 1 \\
Total & $\mathbf{3 5}$ & $\mathbf{2 8}$ & $\mathbf{2 6}$ & $\mathbf{2 0}$ \\
\hline
\end{tabular}


Table 7 Number of potential glucocorticoid side effects, obtained by checklist

\begin{tabular}{|c|c|c|c|c|c|}
\hline & Run-in & $\begin{array}{l}\text { Budesonide } \\
3 \mathrm{mg}\end{array}$ & $\begin{array}{l}\text { Budesonide } \\
9 \mathrm{mg}\end{array}$ & $\begin{array}{l}\text { Prednisolone } \\
7.5 \mathrm{mg}\end{array}$ & Placebo \\
\hline Acne & 6 & 4 & 1 & 2 & 3 \\
\hline Bruising easily & 26 & 10 & 7 & 4 & 5 \\
\hline Buffalo hump & 5 & 2 & 1 & 2 & 1 \\
\hline Depression & 16 & 8 & 6 & 6 & 4 \\
\hline Hirsutism & 1 & 1 & 0 & 0 & 0 \\
\hline Hair loss & 15 & 2 & 4 & 3 & 2 \\
\hline Insomnia & 30 & 10 & 13 & 10 & 10 \\
\hline Mood swings & 15 & 7 & 5 & 4 & 6 \\
\hline Moon face & 3 & 3 & 1 & 0 & 1 \\
\hline Skin striae & 3 & 1 & 0 & 1 & 0 \\
\hline Swollen ankles & 25 & 8 & 8 & 8 & 9 \\
\hline Total & 147 & 56 & 46 & 40 & 41 \\
\hline
\end{tabular}

Our results suggest there was no additional effect of budesonide over and above the systemic benefits of glucocorticoid treatment, in spite of a presumed strong local effect on the terminal ileum. In other conditions associated with bowel pathology the time course of the response may be longer than the three months treatment period of the present study. For example, in coeliac disease the skin inflammation usually improves later than three months after withdrawal of gluten. It is possible, therefore, that a longer time course of treatment with budesonide would be required to obtain additional benefits. If new evidence were to point to such a possibility, then a longer term study should be considered. Other conditions, such as spondyloarthropathy, in which the gut has been implicated more directly in the disease process, and where glucocorticoids are not normally the treatment of choice, may prove more responsive to budesonide than to prednisolone. It would be worthwhile carrying out a comparable study in such patients.

While direct questioning about "steroid related" side effects elicited many reports, these were of similar frequency in all treatment groups, and many were also present at the screening visit before any glucocorticoid treatment. This result questions the notion of the selected category of potential GCS side effects in this group of patents. It also indicates the need for care in the interpretation of adverse effect reporting in non-blinded or uncontrolled studies. No new adverse events were seen compared with previous studies with budesonide in Crohn's disease. Neither were any adverse events reported after discontinuation of the trial medication which might have suggested adrenal insufficiency. Direct measurement of adrenal function will be analysed and reported elsewhere. While there was an increase in symptoms once glucocorticoids were discontinued, patients became no worse off than if they had been taking placebo treatment, and there was no evidence of a "rebound effect" on discontinuation of glucocorticoid treatment.

Overall, this carefully conducted study shows that the symptomatic benefits of budesonide $9 \mathrm{mg}$ and prednisolone $7.5 \mathrm{mg}$ are achieved within a week or two of initiating treatment, are maintained for three months, and are not associated with any "rebound" in symptoms after stopping treatment.

\section{ACKNOWLEDGEMENTS}

The study was administered and funded by Astra-Zeneca. Independent coordinating investigators (JRK, RH, HM, and FW) supervised the writing of the protocol, the analysis, and the interpretation of the results.

\section{Authors' affiliations}

J R Kirwan, Rheumatology Unit, Bristol Royal Infirmary, Bristol, UK
R Hällgren, A Mohammad, Department of Rheumatology, Akademiska Sjukhuset, Uppsala, Sweden

H Mielants, F Van den Bosch, Department of Rheumatology, University Hospital of Gent, Gent, Belgium

F Wollheim, M Leirisalo-Repo, Department of Rheumatology, Lund University Hospital, Lund, Sweden

E Biorck, T Persson, Astrazeneca R\&D Lund, Sweden

C Book, Department of Rheumatology, Universitetssjukhuset MAS, Malmö, Sweden

S Bowman, Department of Rheumatology, Birmingham Heartlands and Solihull Hospital NHS Trust, Birmingham, UK

M Byron, Department of Rheumatology, Weston General Hospital, Weston Super Mare, Avon, UK

N Cox, Department of Rheumatology, Royal Hants County Hospital, Winchester, Hampshire, UK

M Field, Centre for Rheumatic Diseases, University Department of Medicine, Glasgow Royal Infirmary, Glasgow, UK

L Kanerud, Department of Rheumatology, Huddinge University Hospital, Huddinge, Sweden

M Malaise, Department of Rheumatology, CHU Sart-Tilman-Bat B35, Liège, Belgium

R Palmer, Rheumatology Clinic, Solihull Hospital, Solihull, West Midlands, UK

I Petersson, Spenshult, S-313 92 Oskarsström, Sweden

B Ringertz, Department of Rheumatology, Karolinska Sjukhuset,

Stockholm, Sweden

P Sheldon, Department of Rheumatology, Leicester Royal Infirmary, Leicester, UK

N Snowden, Department of Rheumatology, North Manchester General Hospital, Manchester, UK

\section{REFERENCES}

1 Sheldon P. Rheumatoid arthritis and gut related lymphocytes: the iteropathy concept. Ann Rheum Dis 1988;47:697-700.

2 Porzio V, Biasi G, Corrado A, De Santi M, Vindigni C, Viti S, et al. Intestinal histological and ultrastructural inflammatory changes in spondyloarthropathy and rheumatoid arthritis. Scand J Rheumatol 1997;26:92-8.

3 Toivanen P. From reactive arthritis to rheumatoid arthritis. Autoimmunity 2001; 16:369-71.

4 St Clair EW, Wilkinson WE, Pisetsky DS, Sexton DJ, Drew R, Kraus VB, et al. The effects of intravenous doxycycline therapy for rheumatoid arthritis: a randomized, double-blind, placebo-controlled trial. Arthritis Rheum $2001 ; 44: 1043-7$.

5 Cordain L, Toohey L, Smith MJ, Hickey MS. Modulation of immune function by dietary lectins in rheumatoid arthritis. $\mathrm{Br} J$ Nutr 2000;83:207-17

6 Muller H, de Toledo FW, Resch KL. Fasting followed by vegetarian diet in patients with rheumatoid arthritis: a systematic review. Scand J Rheumatol 2001;30:1-10.

7 Mielants H, Veys EM, Cuvelier C, De Vos M. Course of gut inflammation in spondylarthropathies and therapeutic consequences. Baillieres Clin Rheumatol 1996; 10:147-64.

8 Veys EM, Mielants H, De Vos M, Cuvelier C. Spondylarthropathies: from gut to target organs. Baillieres Clin Rheumatol 1996;10:123-46.

9 Gotzsche PC, Johansen HK. Short-term, low-dose corticosteroids and nonsteroidal anti-inflammatory drugs for rheumatoid arthritis. The Cochrane Library. Oxford: Update Software, 1999.

10 Saag KG, Criswell LA, Sems KM, Nettleman MD, Kolluri S. Low-dose corticosteroids in rheumatoid arthritis: a meta-analysis of their moderate-term effectiveness. Arthritis Rheum 1996;39:1818-25. 
11 van Everdingen AA Jacobs JW, Siewertsz Van Reesema DR, Biilsma JW Low-dose prednisone therapy for patients with early active rheumatoid arthritis: clinical efficacy, disease-modifying properties, and side effects: a randomized, double-blind, placebo-controlled clinical trial. Ann Intern Med 2002 Jan 1;136:1-12.

12 Kirwan JR, ARC Low Dose Glucocorticoid Study Group. The effect of glucocorticoids on joint destruction in rheumatoid arthritis. N Engl J Med 1995;333: 142-6.

13 Edsbäcker S, Wollmer P, Nilsson A, Nilsson M. Pharmacokinetics and gastrointestinal transit of budesonide controlled ileal release (CIR) capsules [abstract]. Gastroenterology 1993; 104:A695.

14 Edsbäcker S, Larsson P, Nilsson M, Wirén JE. Budesonide controlled ileal release (CIR) capsules affect plasma cortisol less than prednisolone [abstract]. Gastroenterology 1995; 108(suppl 4):A814.

15 Danielsson Å, Hellers G, Lyrenäs E, Löfberg R, Nilsson Å, Olsson O, et al. A controlled randomized trial of budesonide versus prednisolone retention enemas in active distal ulcerative colitis. Scand J Gastroenterol 1987;22:987-92.

16 Tarpila S, Turunen U, Seppälä K, Aukee S, Pikkarainen P, Elomaa I, et al. Budesonide enema in active haemorrhagic proctitis: a controlled trial against hydrocortisone foam enema. Aliment Pharmacol Ther 1994:8:591-5.

17 Rutgeerts P, Löfberg R, Malchow H, Lamers C, Olaison G, Jewell D, et al. A comparison of budesonide with prednisolone for active Crohn's disease. N Engl J Med 1994;331:842-5.

18 Östergaard Thomsen O, Cortot A, Jewell D, Wright JP, Winter T, Tavarela Veloso F, et al. A comparison of budesonide and mesalazine for active Crohn's disease (the international budesonide-mesalamine study group) N Engl J Med 1998;339:370-4.

19 Arnett FC, Edworthy SM, Bloch DA, McShane DJ, Fries JF, Cooper NS, et al. The American Rheumatism Association 1987 revised criteria for the classification of rheumatoid arthritis. Arthritis Rheum 1988;31:315-24.

20 Steinbrocker O, Traegar CH, Batterman RC. Therapeutic criteria in rheumatoid arthritis. JAMA 1949;140:659-62.

21 Boers M, Tugwell P, Felson DT, van Riel PL, Kirwan JR, Edmonds JP, et al. World Health Organization and International League of Associations for Rheumatology core end points for symptom modifying antirheumatic drugs in rheumatoid arthritis clinical trials. J Rheumatol 1994-21(suppl 41):86-9.

22 Fuchs HA, Brooks RH, Callahan L Pincus T. A simplified twenty-eight-joint quantitative articular index in rheumatoid arthritis. Arthritis Rheum 1989;32:531-7
23 Fries JF, Spitz P, Kraines RG, Holman HR. Measurement of patient outcome in arthritis. Arthritis Rheum 1980;23:137-45.

24 MAPI Research Institute. Cultural adaption of the health assessment questionnaire (HAQ) into Belgian Dutch, Belgian French, Swedish and UK English. Report prepared by MAPI Research Institute, August 1998. Report on file, at AstraZeneca, Lund, Sweden.

25 Kirwan JR, Reeback JS. Stanford Health Assessment Questionnaire modified to assess disability in British patients with rheumatoid arthritis. Br J Rheumatol 1986:25:206-9

26 Ware J, Sherbourne DC. The MOSS 36 item short-form health survey (SF-36). Med Care 1992;30:473-83.

27 Felson DT, Anderson JJ, Boers M, Bombardier C, Furst D, Goldsmith C, et al. American College of Rheumatology. Preliminary definition of improvement in rheumatoid arthritis. Arthritis Rheum 1995;38:727-35.

28 Edsbäcker S, Nilsson M, Larsson P. A cortisol suppression dose-response comparison of budesonide in controlled ileal release capsules with prednisolone. Aliment Pharmacol Ther 1999;13:219-24.

29 Criswell LA, Saag KG, Sems KM, Welch V, Shea B, Wells G, et al. Moderateterm, low-dose corticosteroids for rheumatoid arthritis (Cochrane review). The Cochrane Library, Issue 4. Oxford: Update Software, 2000.

30 Empire Rheumatism Council Subcommittee. Multi-Center controlled tria comparing cortisone acetate and acetyl salicylic acid in the long-term treatment of rheumatoid arthritis. Ann Rheum Dis 1955;14:353-63.

31 Harris E D, Emkey RD, Nichols JE, Newberg A. Low dose prednisone therapy in rheumatoid arthritis: a double blind study. J Rheumato 1983;10:713-21.

32 Million R, Poole P, Kellgren, H, Jayson MIV. Long-term study management of rheumatoid arthritis. Lancet 1984;

33 Stenberg VI, Fiechtner JJ, Rice JR, Miller DR, Johnson LK. Endocrine control of inflammation: rheumatoid arthritis double-blind, crossover clinical trial. Int J Clin Pharmacol Res 1992;12:11-18.

34 Van Gestel AM, Laan RFJM, Haagsma CJ, van de Putte LBA, van Riel PLCM. Low-dose oral steroids as bridge therapy in rheumatoid arthritis patients starting with parenteral gold: a randomized double-blind placebo-controlled trial. Br J Rheumatol 1995; 34:347-51.

35 Van Schaardenburg D, Valkema R, Dijkmans BAC, Papapoulos S, Zwinderman $\mathrm{AH}, \mathrm{Han} \mathrm{KH}$, et al. Prednisone for elderly-onset rheumatoid arthritis: outcome and bone mass in comparison to treatment with chloroquine. Arthritis Rheum 1995:38:334-42.

36 Ritchie DM, Boyle JA, Mclnnes JM, Jasani MK, Dalakos T, Grieveson P, et al. Clinical studies with an articular index for the assessment of joint tenderness in patients with rheumatoid arthritis. Q J Med 1968;147:393-406. 